\section{Keefektifan Penerapan Model Pembelajaran Direct Instruction dalam Pembelajaran Biologi Materi Kingdom Monera pada Siswa Kelas X MAN 1 Makassar}

\author{
Afra Taufiqah \\ Hilda Karim \\ Hamka L
}

\begin{abstract}
Abstrak. Penelitian ini adalah eksperimen semu dengan desain penelitian one group pretest-postest design yang bertujuan untuk mengetahui keefektifan penerapan model pembelajaran direct instruction dalam pembelajaran biologi materi kingdom monera. Sampel penelitian ini dipilih secara acak dan terpilih kelas X MIA 2 sebagai kelas eksperimen. Teknik pengumpulan data melalui pemberian tes sebelum (pretest) dan sesudah (posttest) pembelajaran untuk mengukur hasil belajar peserta didik serta observasi aktivitas belajarpeserta didik selama proses pembelajaran. Teknik analisis data yang digunakan adalah analisis statistic deskriptif dan inferensial dengan uji t. Hasil penelitian menunjukkan bahwa model pembelajaran direct instruction efektif diterapkan dalam pembelajaran biologi kelas X MAN 1 Makassar pada materi Kingdom Monera. Peningkatan hasil belajar peserta didik terlihat pada rata-rata gain ternormalisasi yakni 0,7423 yang berada pada kategori tinggi. Proporsi peserta didik yang mencapai KKM atau berada pada kategori tuntas setelah dibelajarkan dengan model pembelajaran direct instruction sebanyak 78.95\%. Adapun aktivitas peserta didik sebanyak $81.58 \%$ berada pada ketegori aktif. Kata Kunci: direct instruction, hasil belajar, aktivitas belajar.
\end{abstract}

\section{Pendahuluan}

Pada UU No. 20 tahun 2003 tentang sistem Pendidikan Nasional dinyatakan bahwa Pendidikan adalah usaha sadar dan terencana untuk mewujudkan suasana belajar dan proses pembelajaran agar siswa secara aktif mengembangkan potensi dirinya untuk memiliki kekuatan spiritual keagamaan, pengendalian diri, kepribadian, kecerdasan, akhlak mulia, serta keterampilan yang diperlukan dirinya, masyarakat, bangsa, dan Negara (Feriyanjani, 2017).

Pembelajaran pada dasarnya adalah proses penambahan informasi dan kemampuan baru. Informasi dan kemampuan apa yang akan diberikan kepada peserta didik, harus dipikirkan dengan baik oleh guru termasuk mengenai model apa yang akan digunakan agar proses pembelajaran dapat dicapai secara efektif dan efesien. Menurut Trianto (2007) mengajarkan suatu pokok bahasan (materi) tertentu harus dipilih model pembelajaran yang paling sesuai dengan tujuan yang akan dicapai. Oleh karena itu, dalam pemilihan model pembelajaran diperlukan pertimbangan dalam mencocokkan model pembelajaran dan materi yang diajarkan. Hal-hal lain yang perlu diperhatikan dalam memilih model pembelajaran selain materi pelajaran yaitu,

\section{Biology Teaching and Learning}

p-ISSN 2621 - 5527

e-ISSN 2621 - 5535

Abstract. This study is a quasi experimental research design with one group pretest-posttest design that aims to determine the effectiveness of the application of direct instruction learning models in the study of biology in kingdom monera material. The study sample was randomly selected and selected class X MIA 2 as the

experimental class. Data collection techniques through giving tests before (pretest) and after (posttest) learning to measure student learning outcomes and observation of learning activities of students during the learning process.

The data analysis technique used is descriptive and inferential statistical analysis with $t$ test. The results showed that the direct instruction learning model was effectively applied in the biology learning class X MAN 1 Makassar in Kingdom Monera material. Improved student learning outcomes are seen in the normalized gain average of 0.7423 which is in the high category. The proportion of students who reach KKM or in the complete category after being taught with Direct Instruction learning model is $78.95 \%$. The activities of students as much as $81.58 \%$ are in the active category.

Keywords: direct instruction, learning outcomes, learning activities.

Afra Taufiqah

Universitas Negeri Makassar Indonesia

Hilda Karim

Universitas Negeri Makassar Indonesia

Hamka L

Universitas Negeri Makassar Indonesia 
yaitu, tingkat perkembangan kognitif siswa, dan sarana atau fasilitas yang tersedia. Persyaratan utama keefektifan pengajaran, yaitu, 1) Presentasi waktu belajar siswa yang tinggi dicurahkan terhadap KBM, 2) Rata-rata perilaku melaksanakan tugas yang tinggi diantara siswa; 3) ketetapan antara kandungan materi ajar dengan kemampuan siswa (orientasi keberhasilan belajar) 4) Mengembangkan suasana belajar yang akrab dan positif, mengembangkan struktur kelas yang mendukung butir (2) tanpa mengabaikan butir (4) (Khusaimah, 2017).

Pembelajaran yang efektif adalah pembelajaran yang mampu membuat siswa belajar dengan baik dan memperoleh ilmu pengetahuan dan juga keterampilan melalui suatu prosedur yang tepat untuk mencapai hasil belajar sesuai dengan tujuan pembelajaran yang telah ditetapkan. Adapun keefektifan pembelajaran yang dimaksud merujuk pada kualitas dari aspek aktifitas siswa dalam pembelajaran dan hasil belajar siswa.

Menurut Feriyanjani (2017), model direct instruction merupakan salah satu model pembelajaran yang dapat melatih keterampilan proses sains peserta didik dan dapat meningkatan hasil belajar biologi peserta didik. Model direct instruction memiliki karakteristik hampir sama dengan model pembelajaran yang diarahkan oleh pendidik. Pembelajaran ini terfokus pada kegiatan pendidik dan pengorganisasian kelas serta menekankan pada keterlibatan peserta didik dalam mengerjakan tugas dengan pengaturan waktu yang telah disesuaikan.

Tabel 1. Sintaks Model Pembelajaran Direct Instruction

\begin{tabular}{|l|l|}
\hline \multicolumn{1}{|c|}{ Fase } & \multicolumn{1}{c|}{ Peran Guru } \\
\hline $\begin{array}{l}\text { Fase I } \\
\text { Menyampaikan tujuan dan } \\
\text { mempersiapkan siswa. }\end{array}$ & $\begin{array}{l}\text { Guru menjelaskan tujuan pembelajaran, informaasi latar } \\
\text { belakang pelajaran, mempersiapkan siswa untuk belajar. }\end{array}$ \\
\hline $\begin{array}{l}\text { Fase II } \\
\text { Mendemostrasikan pengetahuan atau } \\
\text { keterampilan }\end{array}$ & $\begin{array}{l}\text { Guru mendemostrasikan keterampilan dengan benar, atau } \\
\text { menyajikan informasi tahap demi tahap. }\end{array}$ \\
\hline $\begin{array}{l}\text { Fase III } \\
\text { Membimbing pelatihan }\end{array}$ & $\begin{array}{l}\text { Guru merencanakan dan memberikan bimbingan dan } \\
\text { pelatihan awal. }\end{array}$ \\
\hline $\begin{array}{l}\text { Fase IV } \\
\text { Mengecek pemahaman dan memberikan } \\
\text { umpan balik }\end{array}$ & $\begin{array}{l}\text { Guru mengecek apakah siswa telah berhasil melakukan } \\
\text { tugas dengan baik, memberi umpan balik. }\end{array}$ \\
\hline $\begin{array}{l}\text { Fase V } \\
\text { Memberi kesempatan latihan mandiri. }\end{array}$ & $\begin{array}{l}\text { Guru memberikan tugas kepada siswa untuk menerapkan } \\
\text { keterampilan yang baru saja diperoleh secara mandiri. }\end{array}$ \\
\hline
\end{tabular}

Model pembelajaran direct instruction juga memiliki banyak kelebihan yang diantaranya guru mengendalikan isi materi dan urutan informasi yang diterima oleh siswa sehingga dapat mempertahankan fokus mengenai apa yang harus dicapai oleh siswa. Model pembelajaran direct instruction membuat pelajaran menjadi lebih efektif dikarenakan guru akan lebih banyak menggunakan waktu untuk mendemonstrasikan dan menjelaskan prosedur-prosedur dan keterampilan materi. Melalui fase-fase model pembelajaran direct instruction mendidik para siswa bergerak menuju kemandirian dan tidak lagi bergantung kepada guru dalam pemerolehan pengetahuan. Pada fase membimbing pelatihan dari model pembelajaran direct instruction, guru memberikan beberapa pertanyaan kepada siswa sehinga pada fase tersebut guru membantu siswa membentuk pemahaman sendiri terhadap materi yang sedang dipelajari. Siswa dalam kegiatan pelajaran didorong untuk belajar dengan bertanya, karena pertanyaanpertanyaan mendorong siswa untuk menganalisis suatu permasalahan (Purwantoro, 2016).

Materi kingdom monera termasuk dalam pengetahuan deklaratif dimana sub materi terdiri dari struktur bakteri, macam-macam pengelompokan bakteri, proses perkembangbiakan bakteri serta peranan bakteri. Model direct instruction dapat berbentuk ceramah, demonstrasi, pelatihan, atau praktik dan kerja kelompok. Sehingga diharapkan, melalui konsep ini pembelajaran menjadi efektif dan hasil belajar peserta didik dapat ditingkatkan. 
(hlm. 152-158)

\section{Metode Penelitian}

Penelitian ini merupakan quasy experimental yang bertujuan untuk mengetahui keefektifan penerapan model pembelajaran Direct Instruction yang digunakan pada materi kingdom monera di MAN 1 Makassar. Adapun desain penelitian ini ialah one-group pretest posttest design. Pola desainnya sebagai berikut:
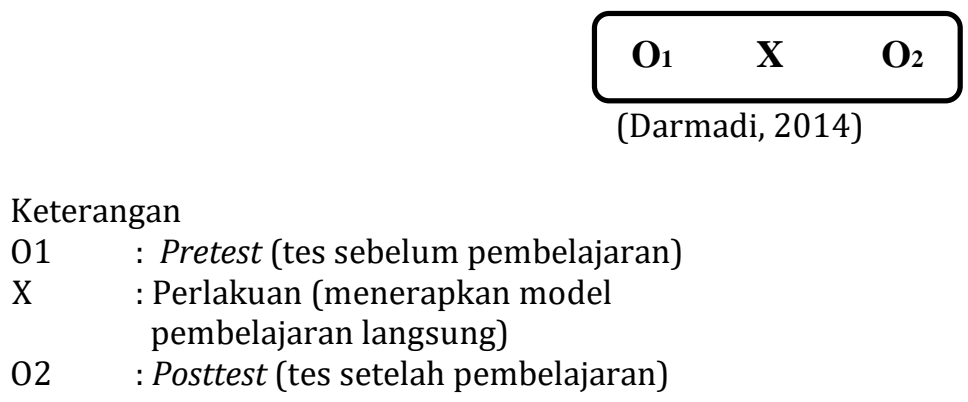

Penelitian ini dilaksanakan di MAN 1 Makassar pada bulan Oktober tahun 2018. Populasi dalam penelitian ini adalah seluruh rombel kelas X MIA MAN 1 Makassar Tahun Ajaran 2018/2019, sedangkan pengambilan sampel dilakukan secara random sehingga terpilih kelas X MIA 2 sebagai kelas eksperimen. Variabel bebas dalam penelitian ini adalah model Direct Instruction dan variabel terikat adalah keefektifan model pembelajaran yang ditinjau dari sub variabel yaitu hasil belajar dan aktivitas peserta didik.

Teknik pengumpulan data yang digunakan dalam penelitian ini adalah tes pilihan ganda untuk mengukur hasil belajar dan lembar observasi aktivitas peserta didik untuk mengukur skor aktovitas peserta didik dalam pembelajaran. Data yang telah terkumpul dengan menggunakan instrumen-instrumen yang ada kemudian dianalisis secara kuantitatif dengan menggunakan teknik analisis statistik. Teknik analisis data yang digunakan yaitu analisis statistik deskripstif dan statistik inferensial dengan menggunakan uji t pada program SPSS 20.0.

\section{Hasil Penelitian}

\section{Hasil analisis deskriptif tes hasil belajar peserta didik}

Tabel 2. Data Statistik Deskriptif Pretest, Posttest, dan $N \_G a i n$ tes Hasil Belajar Peserta Didik

\begin{tabular}{|c|c|c|c|}
\hline & Pretest & Posttest & N_gain \\
\hline Ukuran sampel & 38 & 38 & 38 \\
\hline Rata-Rata & 20.3947 & 78.9474 & 0.7423 \\
\hline Deviasi Standar & 10.29180 & 10.14476 & 0.10899 \\
\hline Variansi & 105.921 & 102.916 & 0.012 \\
\hline Rentang Skor & 30 & 35 & 0.43 \\
\hline Skor Terendah & 5 & 60 & 0.50 \\
\hline Skor Tertinggi & 35 & 95 & 0.93 \\
\hline
\end{tabular}

Tabel 2 menunjukkan bahwa data hasil belajar siswa memperoleh skor rata-rata untuk pretest adalah 20.39 dan untuk posttest adalah 78.94. Skor pretest yang dicapai oleh siswa tersebar dari skor terendah 5 sampai skor tertinggi 35 dengan rentang skor 30. Selanjutnya, skor posttest yang dicapai oleh siswa tersebar dari skor terendah 60.00 sampai skor tertinggi 95.00 dengan rentang skor 35.

Distribusi Frekuensi dan Persentase Ketuntasan Peserta Didik dapat dilihat pada Tabel 3 berikut: 
Tabel 3. Distribusi Frekuensi dan Persentase Ketuntasan Peserta Didik

\begin{tabular}{|c|c|c|c|c|c|}
\hline \multirow{2}{*}{ Kriteria } & \multirow{2}{*}{ Nilai } & \multicolumn{2}{|c|}{ Pretest } & \multicolumn{2}{c|}{ Posttest } \\
\cline { 3 - 6 } & & $\mathbf{F}$ & $\mathbf{\%}$ & $\mathbf{F}$ & $\mathbf{\%}$ \\
\hline Tuntas & $\geq 75$ & 0 & 0 & 30 & 78.95 \\
\hline Tidak tuntas & $<75$ & 38 & 100 & 8 & 21.05 \\
\hline \multicolumn{2}{|c|}{ Jumlah } & 38 & 100 & 38 & 100 \\
\hline
\end{tabular}

Berdasarkan Tabel 3 dapat dikemukakan bahwa skor hasil pretest untuk tes hasil belajar peserta didik kelas X MIA 2 MAN 1 Makassar seluruhya berada pada kategori tidak tuntas sedangkan skor hasil posttest untuk tes hasil belajar peserta didik mengalami peningkatan dengan 30 peserta didik atau 78.95\% berada pada kategori tuntas dan sebanyak 8 peserta didik atau $21.05 \%$ berada pada kategori tidak tuntas. Hasil tersebut menunjukkan penggunaan model pembelajaran Direct Instruction memenuhi kreteria keefektifan dimana lebih dari $75 \%$ peserta didik berada pada kategori tuntas.

Hasil perhitungan N-Gain berdasarkan nilai pretest dan posttest dapat dilihat Tabel 4 berikut:

Tabel 4. Distribusi Frekuensi dan Persentase Gain Ternormalisasi Peserta didik

\begin{tabular}{|c|c|c|c|}
\hline Kategori & Interval & \multicolumn{2}{c|}{$\begin{array}{c}\text { Gain } \\
\text { Ternormalisasi }\end{array}$} \\
\cline { 3 - 4 } & & $\mathrm{F}$ & $\%$ \\
\hline Tinggi & $0,70<$ Gain $\leq 1$ & 25 & 65,79 \\
\hline Sedang & $0,30 \leq$ Gain $\leq 0,70$ & 13 & 34,21 \\
\hline Rendah & Gain $<0,30$ & 0 & 0 \\
\hline \multicolumn{2}{|c|}{ Jumlah } & 38 & 100 \\
\hline
\end{tabular}

Peningkatan hasil belajar berdasarkan Tabel 4 menunjukkan peserta didik berada pada kategori sedang sebanyak 13 peserta didik atau 34.21\% sedangkan sisanya sebanyak 25 peserta didik atau $65.79 \%$ berada pada kategori tinggi. Hasil tersebut menunjukkan rata-rata gain ternormalisasi peserta didik berada pada ketegori tinggi yang berarti penggunaan model pembelajaran Direct Instruction memenuhi kreteria keefektifan dimana minimal rata-rata gain ternormalisasi pada kategori sedang. berikut:

Hasil distribusi frekuensi dan persentase aktifitas peserta didik dapat dilihat pada tabel 5

Tabel 5. Distribusi Frekuensi dan Persentase Aktifitas Peserta didik

\begin{tabular}{|c|c|c|c|}
\hline & & & \\
\hline Kategori & Interval & $\mathbf{F}$ & $\%$ \\
\hline Aktif & $3,50 \leq A \leq 4,0$ & 31 & 81.58 \\
\hline $\begin{array}{l}\text { Cukup } \\
\text { Aktif }\end{array}$ & $2,50 \leq \mathrm{A}<3,50$ & 7 & 18.42 \\
\hline $\begin{array}{c}\text { Kurang } \\
\text { Aktif }\end{array}$ & $1,50 \leq A<2,50$ & 0 & 0 \\
\hline Tidak Aktif & $\mathrm{A}<1,50$ & 0 & 0 \\
\hline & mlah & 38 & 100 \\
\hline
\end{tabular}

Berdasarkan Tabel 5 menunjukkan bahwa peserta didik tersebar pada kategori cukup aktif dan aktif. Sebanyak 7 peserta didik atau $18.42 \%$ pada kategori cukup aktif dan 31 peserta didik atau $81.58 \%$ berada pada ketegori aktif. Presentasi tersebut menunjukkan bahwa ratarata peserta didik berada pada kategori aktif yang berarti penggunaan model pembelajaran 
(hlm. 152-158)

Direct Instruction memenuhi kreteria keefektifan dimana minimal rata-rata aktivitas peserta didik pada kategori cukup aktif.

Analisis statistik inferensial digunakan untuk menguji hipotesis penelitian yang telah dirumuskan. Pengujian ini dilakukan dengan bantuan aplikasi SPSS statistical software (Statistics Product and Service Solutions) 20.0. Statistics hasil analisis uji t diperoleh nilai signifikansi hasil belajar sebesar 0,000. Hal ini menunjukkan bahwa nilai signifikasi lebih kecil dari $0,05(\alpha<0,05)$ yang berarti $\mathrm{H}_{\mathrm{o}}$ ditolak dan $\mathrm{H}_{1}$ diterima.

\section{Pembahasan}

Berdasarkan hasil penelitian yang telah diuraikan, maka secara deskriptif rata-rata skor hasil belajar peserta didik sebelum dan sesudah diajar dengan menggunakan model pembelajaran direct instruction pada materi kingdom monera di MAN 1 Makassar mengalami peningkatan yang dapat dilihat dari adanya perbedaan skor pretest dan posttest peserta didik. Hasil prestest menunjukkan nilai peserta didik tidak memenuhi nilai KKM atau berada pada kategori tidak tuntas dengan rata-rata skor pretest 20.39. Pada hasil posttest mengalami peningkatan sebanyak 30 peserta didik atau $78.95 \%$ telah memenuhi nilai KKM yakni berada pada kategori tuntas dengan rata-rata skor posttest sebesar 78.94 dan nilai tertinggi pada posttest sebesar 95. Tingginya rata-rata skor posttest dibandingkan rata-rata skor pretest peserta didik tersebut menyebabkan rata-rata gain ternormalisasi sebesar 0.7423 yang berarti peningkatan hasil belajar peserta didik berada pada kategori tinggi. Hasil tersebut memenuhi kriteria keefektifan penerapan model pembelajaran dimana persentase ketuntasan peserta didik setelah dibelajarkan dengan model direct instruction berada diatas $75 \%$ dan nilai rata-rata gain ternormalisasai diatas 0.30 .

Rata-rata hasil belajar, presentasi ketuntasan peseta didik, dan N-gain yang tinggi seperti yang telah disebutkan di atas dikarenakan pada proses pembelajaran direct instruction guru mengatur jalannya pembelajaran sehingga langkah-langkah pembelajaran menjadi terarah yang dimulai dengan mempersiapkan peserta didik untuk belajar dan menyampaikan topik pembelajaran serta tujuan pembelajaran, kemudian penyampaian secara langsung materi pembelajaran tahap demi tahap kepada peserta didik. Pada fase ini, guru memberikan pertanyaan-pertanyaan awal berkaitan topik pembelajaran yakni kingdom monera. Dari pertanyaan tersebut peserta didik dibawa kedalam keadaan pembelajaran yang menyenangkan dimana peserta didik dapat mengungkapkan pengetahuan awalnya tentang materi tersebut dan termotivasi untuk mempelajari lebih lanjut materi kingdom monera. Kemudian guru menyampaikan secara langsung isi materi yang penting untuk diketahui dan dipahami oleh peserta didik sehingga peserta didik dapat dengan mudah menangkap inti materi yang diajarkan dan tujuan pembelajaran dapat tercapai. Hal ini sejalan dengan yang dikemukakan Purwantoro (2016) bahwa model pembelajaran direct instruction memiliki banyak kelebihan yang diantaranya guru mengendalikan isi materi dan urutan informasi yang diterima oleh siswa sehingga dapat mempertahankan fokus mengenai apa yang harus dicapai oleh siswa.

Selain memadukan pembelajaran langsung dengan metode tanya jawab, guru menjelaskan isi materi secara langsung mengunakan beberapa variasi media, seperti power point, video, dan gambar yang menopang proses pembelajaran karena materi yang diajarkan adalah kingdom monera yang bersifat abstrak atau tidak dapat dilihat secara langsung. Media yang digunakan membantu memfokuskan perhatian peserta didik dan untuk lebih memahami penjelasan yang diberikan oleh guru sehingga hasil belajar menjadi meningkat. Hal ini sesuai yang dikemukakan Eis (2015) bahwa model pembelajaran langsung (Direct Instruction) disertai media dalam penerapannya di dalam kelas berperan sebagai alat bantu untuk membangkitkan motivasi dan merangsang anak untuk belajar. Agar siswa lebih mudah memahami konsepkonsep tersebut, maka siswa masih sangat membutuhkan benda-benda untuk menolong 
pengembangan kemampuan intelektual, salah satu benda yang dapat menolong siswa dalam hal tersebut adalah gambar.

Peningkatan hasil belajar peserta didik setelah dibelajarkan dengan model direct instruction juga disebabkan karena tugas yang diberikan kepada peserta didik pada fase membimbing pelatihan. Pada fase ini, guru berperan memberikan bimbingan awal kepada peserta didik dalam mengerjakan tugas. Tugas yang diberikan kepada peserta didik berupa soal-soal yang lebih mendalam berkaitan materi dan tugas pembuatan laporan tertulis terkait contoh penerapan bakteri dalam kehidupan sehari-hari sehingga dalam pengerjaannya peserta didik dituntut untuk belajar secara mandiri dan tidak lagi bergantung pada guru dengan melakukan kajian literatur dan membentuk pemahaman sendiri terhadap materi yang sedang dipelajari. Setelah tugas selesai dikerjakan oleh peserta didik, guru mengecek apakah peserta didik telah berhasil mengerjakan tugas dengan baik dan memberi umpan balik. Melalui fase ini waktu belajar peserta didik tidak hanya digunakan untuk pemberian materi secara langsung oleh guru, namun juga digunakan oleh peserta didik untuk mengkonstruksi sendiri pemahamannya melalui kajian literatur. Hal ini sesuai yang dikemukakan oleh Arsyad (2015) bahwa tujuan utama model direct instruction adalah untuk memaksimalkan penggunaan waktu belajar siswa. Beberapa temuan dalam teori perilaku dihubungkan dengan waktu yang digunakan oleh siswa dalam belajar atau mengerjakan tugas dan kecepatan siswa untuk berhasil dalam mengerjakan tugas. Dengan demikian, model pembelajaran langsung dirancang untuk menciptakan lingkungan belajar terstruktur, dan berorientasi akademik.

Peningkatan hasil belajar peserta didik yang telah dijelaskan sebelumnya juga berhubungan dengan keaktifan peserta didik selama proses pembelajaran. Berdasarkan analisis deskriptif aktifitas belajar peserta didik menunjukkan persentase peserta didik yang dibelajarkan dengan model direct instruction sebesar $81.58 \%$ atau sebanyak 31 peserta didik berada pada kategori aktif dan $18.42 \%$ atau 7 peserta didik berada pada kategori cukup aktif. Hasil tersebut memenuhi kriteria keefektifan penerapan model pembelajaran yakni rata-rata aktifitas peserta didik yang dibelajarkan dengan model direct instruction pada materi kingdom monera di MAN 1 Makassar minimal berada pada kategori cukup aktif.

Berdasarkan pemaparan diatas menunjukkan bahwa model direct instruction efektif diterapkan dalam pembelajaran, hal ini sejalan yang dikemukakan oleh Purwantoro (2016) bahwa model pembelajaran direct instruction efektif diterapkan pada kompetensi dasar memahami komponen sistem pendingin. Selain itu, menurut Utama (2014) berdasarkan hasil penelitian penerapan model Direct Instruction pada pembelajaran biologi SMA dapat meningkatkan hasil belajar siswa.

\section{Kesimpulan}

Berdasarkan hasil analisis data hasil belajar dan aktivitas peserta didik maka disimpulkan bahwa model pembelajaran Direct Instruction efektif diterapkan dalam pembelajaran biologi kelas X MAN 1 Makasssar pada materi Kingdom Monera. Peningkatan hasil belajar peserta didik terlihat pada rata-rata gain ternormalisasi yakni 0,7423 yang berada pada kategori tinggi. Proporsi peserta didik yang mencapai KKM atau berada pada kategori tuntas setelah dibelajarkan dengan model pembelajaran direct instruction sebanyak 78.95\%. Adapun aktivitas peserta didik sebanyak $81.58 \%$ berada pada ketegori aktif.

\section{Referensi}

Arsyad, Nur, M \& Hamka. (2015). Keefektifan Penerapan Model Pembelajaran Langsung pada Materi Sistem Gerak di SMA Negeri 1 Donri-Donri. Jurnal Bionature, 16 (1), 58-64 
(hlm. 152-158)

Darmadi, H. (2014). Metode Penelitian Pendidikan dan Sosial. Bandung. Alfabeta.

Eis, (2015). Pengaruh Model Pembelajaran Langsung (Direct Instruction) Disertai Media Gambar terhadap Hasil Belajar Biologi Siswa Kelas VII SMP Negeri 1 Tambusai Utara. Skripsi. Universitas Pasir Pengaraian.

Feriyanjani, D. (2017). Perbedaan Model Project Based Learning dan Model Direct Instruction Ditinjau dari Aspek Keterampilan Proses Sains dan Peningkatan Penguasaan Materi Fisika Peserta Didik SMA. Skripsi. Yogyakarta. Universitas Negeri Yogyakarta.

Khusaimah, Nurul D. (2017). Efektivitas Penerapan Model Pembelajaran Kooperatif Tipe Tai dengan Pendekatan Kontekstual-Saintifik dalam Pembelajaran Matematika pada Siswa Kelas VII SMP Negeri 2 Bontonompo Selatan Kabupaten Gowa. Tesis: Universitas Negeri Makassar.

Purwantoro, K.J. (2016). Penerapan Model Pembelajaran Direct Instruction untuk Meningkatkan Hasil Belajar Mata Pelajaran Sistem Pendingin. Jurnal Pendidikan Teknik Mesin, 16 (1), 21-24.

Utama, C., Kentjananingsih \& Rahayu. (2014). Penerapan Media Pembelajaran Biologi SMA dengan Menggunakan Model direct Instruction untuk Meningkatkan Hasil Belajar Siswa. Jurnal Pena Sains. 1 (1), 29-39.

Trianto. (2007). Mendesain Model Pembelajaran Inovatif Progresif. Jakarta. Prestasi Pustaka Publisher.

\begin{tabular}{|l|l|}
\hline Afra Taufiqah & $\begin{array}{l}\text { Jurusan Biologi, FMIPA, Universitas Negeri Makassar } \\
\text { Email: bioafra14@gmail.com }\end{array}$ \\
\hline Hamka L & $\begin{array}{l}\text { Jurusan Biologi, FMIPA, Universitas Negeri Makassar } \\
\text { Email: } \underline{\text { hamka.1 biounm@ yahoo.co.id }}\end{array}$ \\
\hline Hilda Karim & $\begin{array}{l}\text { Jurusan Biologi, FMIPA, Universitas Negeri Makassar } \\
\text { Email: } \underline{\text { hildakarim@yahoo.com }}\end{array}$ \\
\hline
\end{tabular}

